\title{
ADAMTS13 wt Allele
}

National Cancer Institute

\section{Source}

National Cancer Institute. ADAMTS13 wt Allele. NCI Thesaurus. Code C118326.

Human ADAMTS13 wild-type allele is located in the vicinity of 9q34 and is approximately $45 \mathrm{~kb}$ in length. This allele, which encodes a disinteg rin and metalloproteinase with thrombospondin motifs 13 protein, is involved in the processing of von Willebrand factor multimers. Mutation of the gene is associated with cong enital thrombotic thrombocytopenic purpura. 